\title{
Impact of Ownership Characteristics on Modified Audit Opinion in Jordan
}

\author{
Saleh Zaid Alkilani ${ }^{1}$, Wan Nordin Wan Hussin ${ }^{1}$, Basariah Salim ${ }^{2}$ \\ ${ }^{1}$ Othman Yeop Abdullah Graduate School of Business, Universiti Utara Malaysia, Sintok, Malaysia \\ ${ }^{2}$ Tunku Intan Shafinaz Accounting School, Universiti Utara Malaysia, Sintok, Malaysia
}

Email address:

salehalkelani17@gmail.com (S.Z. Alkilani),wannordin@uum.edu.my (W. N.W. Hussin), basa1189@uum.edu.my (B. Salim)

\section{To cite this article:}

Saleh Zaid Alkilani, Wan Nordin Wan Hussin, Basariah Salim. Impact of Ownership Characteristics on Modified Audit Opinion in Jordan. International Journal of Accounting, Finance and Risk Management. Vol. 4, No. 3, 2019, pp. 71-83. doi: 10.11648/j.ijafrm.20190403.11

Received: June 7, 2019; Accepted: July 4, 2019; Published: July 30, 2019

\begin{abstract}
It is well established that ownership characteristics are impacted by the quality of financial reporting. The purpose of this work is to examine the role of ownership characteristics in minimising the prospect of corporates obtaining a modified audit opinion in Jordan. Three ownership characteristics [family ownership (FAOWN), institutional ownership (INOWN) and foreign ownership (FAOWN)] and modified audit opinion were studied. The study used 117 samples of corporates listed on the Amman Stock Exchange (ASE). Logistic regression was employed to analyse the association between the modified audit opinions as a dependent variable and ownership characteristics as independent variables. Ownership characteristics are anticipated to be more successful in improving the quality of financial statement, and thus, reduce the prospect of firm obtaining a modified audit opinion. The analysed results from 2012 to 2016 periods of these corporates in Jordan showed that FAOWN and FOOWN validated this projection. Interestingly, the effect of family and FOOWN improve the quality of financial statement, thereby, reduce the cases of a modified audit opinion. Additionally, the study could not find any association impact between the INOWN and modified audit opinion.
\end{abstract}

Keywords: Modified Audit Opinion, Ownership Structure, Family Ownership, Institutional Ownership, Foreign Ownership

\section{Introduction}

It is well established fact that ownership characteristic has the potential to effect the supervising mechanisms of firms on quality of financial reporting [1-8]. Alzoubi, showed that ownership structure affects the quality of financial reporting and that FAOWN, INOWN, and FAOWN which can end in lowering earnings management [5], and thus, higher quality of financial reporting. Certainly, regulators in several countries have begun focusing on corporate governance (CG) characteristics, particularly ownership characteristics in order to enhance the quality of accounting facts [9].

Further, the external auditors are anticipated to play a supervising role in safeguarding the credibility of financial reports, limiting the opportunistic earnings management, and decreasing the information asymmetry between managers and external stakeholder [3, 10-12]. It is required that audit opinion must convey the level of assurance to financial users the financial statements that accurately and truthfully reproduce a company's underlying fiscal activities [13, 14]. Hence, an auditor's report is a potential way to verify the handiness of financial facts [15]. Standard unmodified opinions are issued when a financial report is ascertained to be factual and free from quantifiable misstatements, irregularities, and sub-standard opinions, this is also termed as 'modified audit opinions' which are issued when audit companies ascertain some problems within [16, 18, 12]. Auditors issue a modified audit opinion to alert the corporates concerning any dubious or questionable accounting disclosures identified within the reports [19, 20]. Questionable accounting disclosure can be as a result of agency problems which include conflicts of interests between managers and their stakeholders [21, 22].

According to agency theory, agency matters are caused by the difference between the interests of stakeholders and managers. The interests of stakeholders should be of superior concern because the corporate's objectives should serve the prosperity of stakeholders [23, 24]. Agency theory implies that ownership and control separation can cause a difference 
in the interests of owners and that of managers [25]. Accordingly, supervising the management activities is critical to safeguarding that the interests of investors are secured and to guarantee whole and consistent financial reporting. Some previous literature about agency theory has said that elevating the ownership characteristics and management of family shareholders lessened agency conflicts [26, 27, 28]. Also, those institutions managed by a family structure have less agency costs and are more effective [2, 29]. To elaborate on this fact, Saidat, Silva and Seaman, revealed that structured companies are less probably to obtain modified audit opinions than non-family structured companies [30]. In Jordan, the predominant type of ownership characteristics is the family business class [31]. Zeitun and Gang Tian highlighted the significance of ownership concentration in listed corporates in Jordan. They discovered that the average of ownership concentration among these corporates is $35 \%$ for non-defaulting corporates and $40 \%$ for defaulting corporates [32].

The relationship between INOWN and the quality of financial statement can be explicated by agency theory which asserted that INOWN can enhance monitoring of management in handling the firm by reducing agency clashes between stakeholders and managers, thereby substantially reduce misreporting of financial information and improve the efficacy of supervising financial statement [33]. It is considered that ownership concentration is the most effective tool that ensures the appropriate management of companies in developing markets $[34,35]$. This is because institutional stakeholders convey the means to manage companies and precisely oversee the directors and handling the management verdicts. Based on the CG standpoint, the influence of large shareholdings companies in developed markets is different from that in developing markets [36]. Foreign ownership as a significant external monitoring role of a company is anticipated to enhance the quality of financial reporting [37, 39]. Alzoubi determined that the higher the level of FOOWN, the less probable the earnings management would happen and, thus, the quality of financial reporting would be greater [5]. Sachs and Warner contended that FOOWN undertakes vital roles in supervising management, in same as the roles performed by large external stakeholders in emerging economies since the foreign owners have positive incentives to safeguard their capital investment [40]. The higher the number of shares managed by foreign partners, the more the foreign partner allots managerial places in the corporate to foreigners, either on the board of commissioners or a board of directors, which aim at aligning the interests of management and stakeholders to enhance the quality of financial reports [5, 41, 38]. All these lead to improved quality of financial reporting thereby decrease the prospect of a corporate obtaining a modified audit opinion.

Moreover, the basis for the effect of ownership structure on the probability of firms obtaining a modified audit opinion is elucidated. Many types of research concerning the $\mathrm{CG}$ have suggested that the ownership characteristic can influence the process of financial reporting because the ownership functions as a supervising tool [42]. An efficient ownership characteristic yield greater quality financial reporting and, thus, less chance to obtain a qualified audit report [43]. This present study anticipates a reverse relationship between ownership characteristics (FAOWN, INOWN, and FOOWN) and the prospect of a corporate in obtaining a modified audit opinion.

An audit opinion is an appropriate metric for measuring the quality of the financial statement. Arfaoui and DamakAyadi stated that the issuing of a modified opinion by an auditor must be considered indication lowering quality of reporting [44]. Conversely, there are limited studies that concentrated on modified audit opinions as a dimension of quality of the financial statement. Only a few scholars have utilized audit opinion as a proxy of quality of financial reporting [4, 44, 46]. Similarly, in Jordan, a limited study has been reported with regards to audit opinion and financial metrics, for instance, Al-Thuneibat, Khamees and AlFayoumi studied audit opinion and share prices [42]. So, this present study extends research on quality of financial reporting using audit opinion as a measure of the quality of financial reporting and tests its relationship with ownership structure and probability of firm obtaining a modified audit opinion and ownership characteristics.

Concerning feasible contributions coupled with the pressure from the Jordanian government on how to realize the good performance of CG that can add to improving the quality of the financial reporting of Jordanian corporates was an inspiration for this study. Likewise, this study can be of great importance to market managers, institutional organisations, and large audit companies. Understanding factors related to audit opinion can act as a support for valuation for risk in the company including the planning process. Likewise, the evidence can be advantageous in supporting supervisory decisions, mainly those that influence the ownership characteristics. Therefore, the outcomes have implications for regulators and supervisors to better equip with an understanding of how ownership characteristics influence audit opinion and improve the quality of financial reporting.

In spite of the noticeable consideration recently given to the role of $\mathrm{CG}$ on corporate performance and earning management, however, little has been studied on its association to the modified audit opinion, as a proxy of the quality of corporate financial reporting. This research adds to the pool of knowledge on CG literature as follow; one, there is limited empirical literature on ownership characteristics and modified audit opinion in Jordan. Two, this study examined the ownership structural patterns in the Jordanian context. Three, irrespective of the increasing concentration on the role of $\mathrm{CG}$, very little study is accessible on its relationship with the issuance of a modified audit opinion [44]. Also, little is reported on its role in improving the quality of financial reporting or its contribution in developing economies such as Jordan, where the stakeholder protection and the use of CG are weak. This work fills in these gaps. Therefore, this work investigates the impact of ownership 
characteristics (FAOWN, INOWN, and FOOWN) on the issuance of a modified auditor opinion in Jordan.

\section{Background and Hypothesis Development}

\subsection{Audit Opinion in Jordan}

Audit reporting is the most important communication instrument use by auditors to update externals about their auditing process [43]. A report produced by the auditor is the ultimate outcome of the auditing process [45], and the reported planning is one of the first responsibilities of an auditor to tender the report to the investors and other related parties. As mandated by article 193, paragraph (g) of the Jordanian Corporates Act No. 22 of 1997, 2017, an auditor must present a written statement to the shareholders and applicable parties $[46,48]$. The audit report must be made in conformity with standard auditing rules, auditing principles, scientific and technical standards [47]. The auditor is responsible for financial statements, which must be prepared according to standards, legislation, regulations, and requirements [49]. One function of an auditor is to ascertain whether the reports prepared by a manager comply with standard accounting principles [5, 47]. An auditor's validation of financial facts increases the reliability of the report and lessens information risk, misrepresentative, and potentially benefiting both corporate owner and manager [57, 51].

One of generally used form of audit opinion is the standard unqualified audit [18], which International Standards on Auditing 700 (ISA, 52, 61, 53, 54] detail defines the content and structure of the unmodified report. In this class, an auditor conveys unmodified (unqualified) opinion when the auditor accomplishes that the financial reports are formulated in all measureable regards in conformity with the relevant financial reporting context. The auditor communicates his/her opinion on the basis of scrutiny and the proof collected of financial statements of an article prepared or provide financial reports of practical assurance free from inaccuracies, fraud, and misstatement. Auditors also issue modified audit reports abstracted as any report other than the unqualified report, including unqualified reports with descriptive paragraphs [18]. Correspondingly, auditors can issue a more severe modification by an adverse opinion or by a disclaimer of opinion [12]. In certain cases, the auditor's report content may be modified as detailed in ISA 700 [61, $53,54]$. The modification of report may be done either by appending an emphasis of matter paragraph or another matters paragraph while the auditor's opinion is still unmodified (unqualified), or by modifying an opinion, in cases in which an auditor alter his/her opinion to qualified or adverse, or issues a disclaimer opinion [114, 115]. The International Auditing and Assurance Standard Board [55] proclaims that in certain situations, an auditor needs to modify his/her opinion in the audit report. These situations are include the auditor is incapable to get adequate and appropriate proof regarding the going concern, the facts incorporated in the financial reports in relationship to going concern is not accurate or convincing, and the auditor disagrees with the use of going concern source in the groundwork of financial statement that is used by the entity's management [55].

Types of audit opinion in Jordan are similar to those in developed nations. There are two major types of opinions: (1) unmodified (unqualified) and (2) modified (qualified) audit opinions [56]. A modified audit opinion is split into four subclasses: unqualified with an emphasis of matter (EOM), qualified, and adverse or disclaimer. Resulting this categorisation, according to the corporates Law 22/1997, 2017 /article (195/b), the auditor must give his final opinion on a company's financial statements (balance sheet and profit and loss account) in one of the following ways: 1) absolute approval (unmodified/unqualified opinion) of the annual sheet, profit, and loss account and cash flow, 2) (unmodified/unqualified opinion), approval with reserve, 3) modified/qualified opinion) of the balance sheet, profit and loss account and cash flow, provided that he states the reasons for such a reservation and its financial effect on the company. and 4) Non-approval (adverse or disclaimer opinion) of the balance sheet, profit, and loss account and cash flows and returning them to the board of directors, with the reasons justifying such a rejection of the balance sheet $[48,57]$.

\subsection{Family Ownership}

Family ownership is the most predominant structure of business establishment throughout the world [58] and occurs in diverse sizes and sectors in both developed and developing countries [59]. It has been contended that a FAOWN structure has distinctive characteristics which offer potential benefits over other types of ownership with regards to performance and effectiveness [60], persistence and durability [61, 62]. Family members have strong motivations to monitor managers and enhance corporate performance, and FAOWN may either contravene or significantly eradicate agency issues emanating from the encounter between shareholders and managers [63]. A family as the owner of a company has management control and the existence of family members on a BoDs offers the family an advantage in supervising the corporate. Also, family members maybe perhaps encouraged to increase their wealth by disregarding the interests of the other stakeholders. In contrast, family members can be generally thoughtful of maximizing the company value [64]. General, the results show that the practices of financial reporting of family companies are of better quality than those of non-family firms. Better quality financial reporting practices in family companies are in line with a long-run investment prospect, status concerns and better supervision of managers [65-69].

The vigorous supervision of family owners decreases the inherent risk of material misstatements in financial reporting, causing lowering in audit effort [70]. Vigorous family participation in management tasks can improve corporate 
performance because they provide effective supervision of management in the process of financial reporting [71, 72]. They found that family companies with good board governance tend to demand greater audit quality by selecting professional auditors and paying much audit fees. Moreover, a family company is interested in passing on its legacy across the generations, so it has a bigger risk repulsion [73]. This long-term forethought can lead a family company to make more careful financial decisions than a non-family firm. Likewise, because FAOWN is concentrated in the hands of a small number of stakeholders, with lower agency costs, such companies can achieve better performance, and are consequently more likely to receive a favourable audit opinion [74], thus, maintaining the quality of financial reporting, and thereby decreasing the prospect of obtaining a modified audit opinion.

Evidently, little empirical study on the association between FAOWN and modified audit opinion has been reported. A Alzoubi assessed the relationship between FAOWN and quality of financial reporting and exposed the significant impact of FAOWN on the quality of financial reporting of corporates in Jordan [5]. A positive relationship between FAOWN and quality of financial reporting [65, 75, 68]. Opposing these results, Jiraporn and DaDalt discovered a negative and significant relationship between FAOWN and quality of financial reporting [76]. Hashmi, Brahmana and Lau revealed a negative and statistically significant between the quality of financial reporting and FAOWN [77]. Low and Majid determined that the association between family business and modified audit opinion is negative, suggesting that family-controlled firms are less probably to obtain modified audit opinions than non-family firms. It appears, thus, that a family business is more prospective to obtain a favourable opinion, particularly if power is concentrated (which results in lower agency costs). Farinha and Viana study using companies listed in the Madrid Stock Exchange from 1999 to 2002. The study examined the effect of ownership concentration, board size, board ownership and family members on the audit report. The findings of the multivariate logistic regression showed that the more the family members working on the BoDs, the more prospective companies are to obtain a modified audit opinion [45]. According to these results, this present study posits a negative relationship between FAOWN and the modified audit opinion as follows:

H1: There is a negative association between family ownership and the prospect that a company will receive a modified audit opinion.

\subsection{Institutional Ownership}

Based on agency theory, the separation of ownership and control cause difference in the chase of the interests of managers and that of owners [25]. Hence, supervising managerial decisions becomes important to ensure that the interests of stakeholders are secure and to safeguard reliable and comprehensive financial reporting [78]. Agency theory indicates that supervising by INOWN can be essential governance structures or characteristics [78, 77, 5]. Main stakeholders such as institutional stakeholders can impact agency costs, the efficacy of supervising managers and corporate performance because of the substantial assets that they have and because of their capability to access relevant obtainable facts. They benefit from numerous advantages permitting them to exercise control at the lowest cost [79]. Furthermore, institutional shareholders have the prospect, resources, and capability to supervise managers. Consequently, INOWN is related with better monitoring of management activities, decreasing the capacity of managers to deviously influence earnings [77], because institutional owners offer effective supervising of management in the process of financial reporting. Yasser, Mamun and Hook revealed that INOWN can play an active role in supervising and castigating managerial decision and in controlling the reporting process [6]. These discoveries indicate that INOWN can play an active role in supervising and penalising managerial option and in controlling the reporting process, therefore, sustaining the quality of financial reporting, and in turn, decreasing the prospect of obtaining a modified audit opinion.

Obviously, little empirical investigation has been carried out on the relationship between INOWN and modified audit opinion has been reported. Almutairi studied the influence of INOWN and company debts on audit quality, proxies by auditor industry speciality. The results displayed a positive relationship between INOWN and auditor industry specialization [34]. Kouaib and Jarboui studied the relationship between INOWN and audit quality in China. The results revealed that an increase in INOWN led to the overall increase in the demand for higher quality audit in China [80]. Mitra, Hossain and Deis empirically evaluated the association between INOWN and audit quality. The study used audit tenure as a proxy for audit quality and found INOWN to be significantly and positively associated with audit quality [82]. Lassoued, Ben Rejeb Attia and Sassi disclosed a positive and significant relationship between INOWN and earning management [35]. However, Mitra, Hossain and Deis established that INOWN and managerial ownership had no significant relationship with audit quality [82]. While, Soliman and Elsalam discovered a negative association between INOWN and earnings management. Alzoubi disclosed a negative significant association between INOWN and quality of financial reporting [5]. Based on these findings, this present study postulates a negative association between INOWN and the modified audit opinion, as follows:

H2: There is a negative association between institutional ownership and the prospect that a company will receive a modified audit opinion.

\subsection{Foreign Ownership}

Foreign ownership is a CG structure that can decrease agency conflicts. The foreign owners from nations that characteristic good CG will strive to execute good CG in the corporates in which they invested [84, 85, 37]. According to 
An FOOWN alleviates managerial resourcefulness, thus increasing the quality of financial statements [37]. Foreign ownership can achieve better oversight than local stakeholders offer because FOOWN reputational and legal risks if they do not apply good CG [84]. Waweru establish that FOOWN played a decisive role in enhancing the governance of non-US listed corporates [86], while, Aggarwal, Erel, Ferreira and Matos show substantiation that FOOWN had a positive impact on the evaluation and performance of non-US listed firms. One sign of the application of good CG is the choice of external auditor. Foreign ownership that practices good CG can select a high-quality auditor and increase the competence of quality of financial reporting [87]. Ferreira and Matos reported that an increase in FOOWN can also lead to an enhancement in quality of financial reporting, caused by differences enhanced supervision [88], thereby decreases the prospect of firm obtaining a modified audit opinion.

Superficially, no empirical study on the relationship between FOOWN and modified audit opinion has been reported. Beuselinck, Blanco and García Lara examined the role of FOOWN in enhancing the quality of accounting information and found that increases in FOOWN led to increases in the quality of financial reporting [89]. Lee, Rhee and Yoon explored the effects of both foreign majority stakeholders and foreign investors' participation on the board of directors on audit quality and establish that the presence of foreign investors such as foreign block stakeholders and foreign outside directors increased audit quality [38]. An studied how FOOWN affects the quality of financial reporting of firms listed on the Korean Stock Exchange and observed that FOOWN is positively linked with the quality of financial reporting. Beuselinck, Blanco and Garcia Lara studied the relationship between corporate ownership structures and audit fees paid to external auditors by Malaysian corporates listed on Bursa Malaysia [90]. They establish a significant and positive association between audit fees and firms with larger FOOWN. Nelson and MohamedRusdi found a positive and significant relationship between audit quality and that of corporates with both foreign and INOWN [91]. Contrary to these findings, de Albornoz Noguer and Rusanescu, who assessed the FOOWN and quality of financial reporting, found a negative relationship between FOOWN and quality of financial reporting in Spain [41]. Alzeaideen and Al-Rawash exposed a negative association between FOOWN and quality of financial reporting [92]. Alzoubi disclosed a negative and significant association between INOWN and quality of financial reporting [5]. Guo, Huang, Zhang and Zhou found that FOOWN did not have any relationship with the audit report lag [93]. Based on these results, this study suggested a negative relationship between FOOWN and the modified audit opinion as follows:

H3: There is a negative association between foreign ownership and the prospect that a company will receive a modified audit opinion.

\section{Methodology}

\subsection{Sample and Data}

The scope of the study is to assess the association of ownership structure with a modified auditor opinion in Jordan. The sample in this research will be the services and industry sectors. These sectors were chosen because they play an essential role in the fiscal development of Jordan $[94,95]$ and because several Jordanian corporates in these sectors have experienced bankruptcy. This study utilizes data from 2012 to 2016, which is after the enactment of the Jordanian corporate code of governance in 2009. These periods were selected because the data are obtainable and adequate to serve the purposes of this study [96]. Financial sectors were excluded from the sample because of their distinctive characteristics and the particular rules and requirements for their annual reports as they are subjected the rules of governance issued by the central bank and the insurance regulatory act, which differ from those of public shareholding corporates and this may have an influence on the results. The sample consists of 117 corporates that had the accessible data required for the study. Data on modified audit opinion and ownership characteristics (FAOWN, INOWN, and FOOWN) issued to Jordanian firms were collected from ASE webpage. Data about ownership structure and modified audit opinion were collected from the annual reports for the listed corporates published by JSC. According to manually collected data from the audit opinion reports of Jordanian listed corporates, most Jordanian publiclisted corporates that obtained modified audit opinions in the sample had a lower quality of the financial statement. This is because the majority of these corporates failed to provide adequate or applicable audit proof, which shows the lower quality of their financial reporting.

\subsection{Model and Variables}

To test three hypotheses of the present study, the following logistic regression is used to models the prospect that the auditor will issue a modified opinion: The algorithm for the model is

$\mathrm{MAO}=\beta 0+\beta 1 \mathrm{FAOWN}+\beta 2 \mathrm{INOWN}+\beta 3 \mathrm{FOOWN}+\beta 4$ $\operatorname{LogAuLag}+\beta 5 \operatorname{LogAF}+\beta 6$ BIG4 $+\beta 7 \mathrm{LEV}+\beta 8$ LNASSETS $+\beta 9$ Loss $+\beta 10$ AUEFFORT $+\beta 11$ SWITCH $+\varepsilon$

Table 1. Variables and Measurement.

\begin{tabular}{lll}
\hline Variable & Abbreviation & Measurement \\
\hline Modified Audit opinion & MAO & 1 if a company obtained modified audit opinion, and 0 if otherwise \\
Family Ownership & FAOWN & Proportion of common stock owned by family members \\
Institutional Ownership & INOWN & Measured by the percentage of the total shares owned by institutions \\
Foreign Ownership & FOOWN & Measured as the percentage of the total shares owned by non-Jordanian investors in the company \\
Audit Lag & LogAuLag & The logarithmic of audit report lag \\
\hline
\end{tabular}




\begin{tabular}{|c|c|c|}
\hline Variable & Abbreviation & Measurement \\
\hline Audit Fees & LogAF & The logarithmic of external audit fees \\
\hline Audit Firm Size & BIG4 & Dummy variable that equals 1 if the auditor is a Big 4 and 0 if otherwise \\
\hline Leverage & LEV & The total liabilities divided by the total assets of firm $\mathrm{i}$ in year $\mathrm{t}$ \\
\hline Firm Size & LNASSETS & The natural logarithm of the total assets of firm $\mathrm{i}$ in year $\mathrm{t}$ \\
\hline Loss & Loss & Dummy variable that equals 1 if the firm reported losses on the previous year, and 0 if otherwise \\
\hline Audit Effort & AUEFFORT & Accounts receivable plus inventory scaled by total assets \\
\hline Audit Switch & SWITCH & $\begin{array}{l}\text { A dummy variable having the value } 1 \text { if the audit partner in year } t \text { of firm } i \text { is a different individual } \\
\text { than in year } t-1 \text {, and } 0 \text { if otherwise }\end{array}$ \\
\hline
\end{tabular}

\subsection{Sample Selection and Description}

The category of modified audit opinion obtained by Jordanian corporates was characterised into unqualified with an explanatory paragraph, qualified opinion reports, disclaimer of opinion reports, and adverse opinion reports. A total of $32.5 \%$ of the annual report of Jordanian corporates obtained a modified audit opinion during the period from 2012 to 2016. The form of modified audit opinion obtained by Jordanian corporates are unqualified with explanatory paragraph (41.8\%), qualified (57.0\%), adverse opinion ( $0.53 \%)$ and disclaimer opinion $(0.53 \%)$, as shown in Table 2.

Table 2. Type of Audit opinion.

\begin{tabular}{|c|c|c|c|c|c|c|c|}
\hline Type of Modified Audit opinion & 2012 & 2013 & 2014 & 2015 & 2016 & Total & Percentage \\
\hline Unqualified with explanatory paragraph & 14 & 18 & 18 & 15 & 14 & 79 & $41.80 \%$ \\
\hline Qualified & 19 & 19 & 22 & 24 & 24 & 108 & $57.0 \%$ \\
\hline Adverse opinion & 0 & 1 & 0 & 0 & 0 & 1 & $0.53 \%$ \\
\hline Disclaimer opinion & 0 & 0 & 0 & 1 & 0 & 1 & $0.53 \%$ \\
\hline Total & 33 & 38 & 40 & 40 & 38 & 189 & $100 \%$ \\
\hline
\end{tabular}

Based on ISA [52, 61, 53, 54], external auditor issues a modified audit opinion because of three main reasons: (1) inadequacy of the proper audit evidence, (2) going concern opinion, 3) a mixture inadequacy of the proper audit evidence and going concern opinion. Table 3 displays the reasons why external the auditor issued a modified audit opinion. These findings indicate that most corporates in Jordan who obtained a modified audit opinion obtained one because of the inadequacy of the appropriate audit evidence (which is referred to as a limitation of the audit scope), which indicates a lower quality of their financial reporting. Hence, a modified audit opinion may be a direct proxy for the quality of financial reporting. About $32.3 \%$ of the sampled corporates obtained a modified audit opinion because of a going concern opinion from the external auditor and about $18.5 \%$ obtained a modified audit opinion because of both inadequate evidence and a going concern opinion.

Table 3. Reasons for Modified Audit opinions.

\begin{tabular}{llllllll}
\hline & $\mathbf{2 0 1 2}$ & $\mathbf{2 0 1 3}$ & $\mathbf{2 0 1 4}$ & $\mathbf{2 0 1 5}$ & $\mathbf{2 0 1 6}$ & Total & Percentage \\
\hline Inadequacy & 20 & 21 & 16 & 18 & 18 & 93 & $49.2 \%$ \\
Going concern opinion & 10 & 12 & 13 & 15 & 11 & 61 & $32.3 \%$ \\
Both & 3 & 5 & 11 & 7 & 9 & 35 & $18.5 \%$ \\
Total & 33 & 38 & 40 & 40 & 38 & 189 & $100.0 \%$ \\
\hline
\end{tabular}

\section{Analysis and Result}

\subsection{Descriptive Analysis}

The descriptive statistics for the study variables are shown in Table 4. It displays that the mean for the FAOWN variable is $24 \%$ form the sampled listed companies in Jordan. The mean of INOWN is $8.85 \%$ and mean for FOOWN is $7.39 \%$. This information showed that the percentage of FAOWN is higher than both institutional and FOOWNs which indicating that the largest number of corporates have FAOWN.

The mean value of audit lag is 59.4, which indicate more than average, while audit reports are disclosed 59 days after the audit report date for the company in the sample. The mean of audit fees LN was about $9.19 \%$ about 14.280 JOD (Jordanian Dinar) ranging from 2.09 to about $8.120 \mathrm{JOD}$ to (11.766) 128.118 JOD with a standard deviation of 0.97 about 17.366 JOD. This suggests that some Jordanian corporates do not follow the guidance of the Jordanian Association of Certified Public Accountants (JACPA), which suggests that the minimum audit fees should be 7500 JOD. The mean of Big4 was $67 \%$, indicating that about $67 \%$ of corporates in the sample were audited by Big 4 audit firms (Ernst \& Young, Deloitte \& Touche, and KPMG and PricewaterhouseCoopers). The mean of leverage $37.5 \%$ signifies that the higher amount of leverage contributes to the higher acceptance of modified audit report. This figure is similar to the average leverage reported by Al-Fayoumi, Abuzayed \& Alexander and Alabdullah, Yahya \& Ramayah. Approximately 34\% of companies reported losses in the earlier year, and if a company experiences a loss in the preceding year then resulted in the incidence of a modified audit opinion. This is consistence with Chen, Peng, Xue, Yang and Ye who found that firms with accounting losses are more probable to receive modified (unfavourable) opinions [14]. This figure is similar to the relationship of average loss and Big 4 auditors in a study 
conducted in Jordan by Alzoubi. The average audit effort is 9066, demonstrating that auditors devote some work to examining material misstatements to fulfil their votive responsibilities. An audit partner switch has taken place for $16.2 \%$ of all firm-years (SWITCH).

Table 4. Descriptive Statistics.

\begin{tabular}{|c|c|c|c|c|}
\hline Variable & Mean & Std. Dev. & Min & Max \\
\hline ModifiedAu $\sim \mathrm{n}$ & 0.204 & 0.403 & 0 & 1 \\
\hline FamilyOnwe $\sim$ p & 24.184 & 27.356 & 0 & 100 \\
\hline Institutio $\sim p$ & 8.828 & 15.119 & 0 & 98.6 \\
\hline auditlagLN & 3.960 & 0.542 & 1.792 & 5.204 \\
\hline auditfeesLIN & 9.192 & 0.930 & 2.094 & 11.766 \\
\hline audit fees in (JD) & 2.09 & 17.366 & 8.120 & 128.118 \\
\hline leverage & 37.245 & 29.990 & -205 & 179.633 \\
\hline totalasset $\sim \mathrm{N}$ & 3.239 & 24.577 & -75.611 & 286.519 \\
\hline loss & 0.3489 & 0.477 & 0 & 1 \\
\hline auditeffort & 9066.246 & 35422.12 & 0.0001 & 424436 \\
\hline auditswitch & 0.162 & 0.369 & 0 & 1 \\
\hline
\end{tabular}

\subsection{Analysis of Logistic Regression: Correlation Analysis (Pearson Correlation Matrix) for Variables}

The result of the correlation for the variables is shown in Table 5. According to Idris, Siam and Nassar, the general rule of thumb is that if a simple correlation coefficient between two regressors is greater than 0.8, then multicollinearity is a serious issue [98]. The correlations are quite low, generally below 0.3 except for a loss, which is correlated at $0.31 \%$ with $0.01 \%$ level of significant in a positive direction. This provides an indication that multicollinearity is not a problem in either of the model estimations. It means that the companies with accounting losses are more probably to receive a modified audit opinion. The correlation-matrixes highlight that the values of correlation obtained for the variables in modified audit opinion are less than 0.80 . This suggests that multicollinearity is lacking among the descriptive variables in the models. Among the independent variables, the highestcorrelation is 0.3133 for the modified audit opinion. All the variables have a correlation below the critical limits of 0.80 , as shown in Table 5. This indicates that multicollinearity is not a problem in either of the model estimations.

The Pearson correlation analysis for the key variables is Table 5. Aligning with hypotheses, H1, and $\mathrm{H} 3$ modified audit opinion was negatively correlated with family and FOOWN at the $1 \%$ levels, suggesting that FAOWN and FOOWN serve as monitoring mechanisms that enhance the quality of financial reporting and thereby reduce the prospect of the company obtaining a modified audit opinion. With respect to $\mathrm{H} 2$, a modified audit opinion was positively correlated with INOWN. The Pearson correlation analysis for the control variable, modified audit opinion, was positively correlated with audit report lag, big4, leverage, loss, audit effort, and auditor switch. While modified audit opinion was negatively correlated with audit fees and company size. Generally, the results indicate that less correlation existed between the variables used, therefore, decreasing concern about multicollinearity and allowing further data analysis.

Table 5. Pearson Correlation Analysis.

\begin{tabular}{|c|c|c|c|c|c|c|}
\hline & Modifi $\sim n$ & Family $\sim p$ & Instit $\sim p$ & foreig $\sim p$ & auditl $\sim \mathbf{N}$ & auditf $\sim N$ \\
\hline ModifiedAu $\sim \mathrm{n}$ & 1.0000 & & & & & \\
\hline FamilyOnwe $\sim$ p & $-0.1241 * * *$ & 1.0000 & & & & \\
\hline Institutio $\sim p$ & $0.0808 * *$ & $-0.2681 * * *$ & 1.0000 & & & \\
\hline foreignOwn $\sim p$ & $-0.1348 * * *$ & $-0.2626 * * *$ & $-0.0943 * *$ & 1.0000 & & \\
\hline auditlagLN & $0.1477 * * *$ & -0.0268 & $0.0982 * *$ & -0.0532 & 1.0000 & \\
\hline auditfeesLIN & $-0.1058 * *$ & $-0.2302 * * *$ & $0.1552 * * *$ & $0.2237 * * *$ & $0.1291 * * *$ & 1.0000 \\
\hline Big4 & 0.0175 & 0.0116 & $0.1271 * * *$ & $0.1782 * * *$ & $0.2859 * * *$ & $0.2555 * * *$ \\
\hline totalasset $\sim \mathrm{N}$ & -0.0252 & -0.0580 & -0.0131 & $0.0817 * *$ & 0.0670 & $0.1293 * * *$ \\
\hline loss & $0.3133 * * *$ & 0.0456 & -0.0303 & $-0.1228 * *$ & $0.2013 * * *$ & $-0.1781 * * *$ \\
\hline auditeffort & $0.0859 * *$ & -0.0542 & 0.0552 & $0.1461 * * *$ & $0.1294 * * *$ & $0.1872 * * *$ \\
\hline auditswitch & $0.0912 * *$ & -0.0134 & 0.0574 & -0.0089 & $0.0875 * *$ & $-0.1025 * *$ \\
\hline
\end{tabular}

Notes: *. Correlation is significant at the 0.010 level (1-tailed), **. Correlation is significant at the 0.05 level (1-tailed), and ***. Correlation is significant at the 0.001 level $(1-$ tailed $)$.

Table 5. Continued.

\begin{tabular}{llllll}
\hline & Big4 & leverage & totalasset $\sim N$ & loss & auditeffort \\
\hline ModifiedAu $\sim \mathrm{n}$ & & & & \\
FamilyOnwe $\sim \mathrm{p}$ & & & & \\
\hline
\end{tabular}




\begin{tabular}{|c|c|c|c|c|c|c|}
\hline & Big4 & leverage & totalasset $\sim \mathbf{N}$ & loss & auditeffort & auditswitch \\
\hline $\begin{array}{l}\text { Institutio } \sim p \\
\text { foreignOwn } \\
\text { auditlagLN } \\
\text { auditfeesLIN }\end{array}$ & & & & & & \\
\hline Big4 & 1.0000 & & & & & \\
\hline leverage & $0.1727 * * *$ & 1.0000 & & & & \\
\hline totalasset $\sim \mathrm{N}$ & $0.0880 * *$ & -0.0462 & 1.0000 & & & \\
\hline loss & -0.0319 & $0.2146^{* * *}$ & $-0.1009^{* *}$ & 1.0000 & & \\
\hline auditeffort & $0.1286^{* * *}$ & $0.1050 * *$ & $0.1877 * * *$ & -0.0194 & 1.0000 & \\
\hline auditswitch & 0.0220 & 0.0253 & 0.0541 & 0.0118 & 0.0058 & 1.0000 \\
\hline
\end{tabular}

\subsection{Logistic Regression Analysis}

The logistic regression results are present in Table 6. The model consists of independent variables (FAOWN, INOWN, and FOOWN) and control variables (audit fees Ln, audit lag Ln, big4, Leverage, total assets Ln, loss, audit effort and audit switch) with modified audit report as the dependent variable. The result shows $\mathrm{R}$ Square at 19.3, the Wald Chisquare's test at 113.02 and the model is significant at the 0.00 $(p<0.01)$ level. The logistic regression results in Table 6 show that the FAOWN had a significant impact on modified audit opinion at the $1 \%$ level. Conversely, the direction of impact was negative, and this result suggests that an increase in the percentage of FAOWN in the corporate will increase the quality of financial reporting and, in turn, reduce the probability of corporate obtaining a modified audit opinion. This result is in agreement with the results of the earlier studies found that the family control had a significant and negative moderating influence on the relationship between the efficacy of board of directors and corporate performance [77, 5, 99]. However, it is not consistence with results obtained by Makhlouf, Ali and Ramli who discovered a positive and significant association between family control and the type of CPA opinion [100]. The authors discovered that if family control increases the opinion of the independent auditor will have fewer paragraphs. Additionally, since FAOWN is concentrated in the influences of less number of stakeholders, with lesser agency costs, such companies can realize optimal performance, and are subsequently more probably to obtain a favourable opinion [100].

Table 6. Result of the Logistic Regressions.

\begin{tabular}{llll}
\hline Variable & Coef. & $\mathbf{Z}$ & $\mathbf{P}>\mathbf{z}$ \\
\hline FamilyOnwership & -0.020 & -3.87 & 0.000 \\
InstitutionalOwnership & 0.001 & 0.13 & 0.895 \\
foreignOwnership & -0.039 & -2.75 & 0.006 \\
auditlagLN & 0.262 & 0.98 & 0.328 \\
auditfeesLIN & -0.274 & -2.03 & 0.042 \\
Big4 & 0.082 & 0.31 & 0.758 \\
leverage & 0.012 & 2.89 & 0.004 \\
totalassetsLN & 0.001 & 0.12 & 0.903 \\
loss & 1.373 & 5.55 & 0.00 \\
auditeffort & 0.000 & 2.24 & 0.025 \\
auditswitch & 0.541 & 1.82 & 0.068 \\
cons & -0.639 & -0.41 & 0.679 \\
LR chi2 (11) & 113.02 & & \\
Prob $>$ chi2 & 0.00 & & \\
Pseudo R2 & 0.193 & & \\
\hline
\end{tabular}

Likewise, Table 6 displays that the coefficient for the
INOWN is positive and insignificant. This finding shows that the INOWN does not add towards enhancing the firm, thereby boosting the quality of financial statement and does not add towards enhancing the supervising task. Therefore, it does not affect the opportunity of a company to receive an unmodified audit opinion. The result is consistent with the previous studies by Soliman and Elsalam who found that institutional investors had no significant relationship with audit quality [83]. The result is not consistent with earlier findings that INOWN has a positive impact on audit quality (Kouaib \& Jarboui; Chan, Lin \& Zhang; Almutairi; Lassoued, Ben Rejeb Attia \& Sassi).

The logistic regression results in Table 6 show that the FOOWN has a significant effect modified audit opinion at the $1 \%$ level. Nevertheless, the direction of the impact is negative. This result suggests that an increase in the percentage of FOOWN in a company will increase the quality of financial reporting and, thus, minimize the receipt of a modified audit opinion. This result is consistent with earlier finding who studied the association of FOOWN and quality of financial reporting and discovered a negative association between FOOWN and quality of financial reporting in Spain [41]. The result is not consistent with the previous studies by that FOOWN has a positive association with the quality of financial reporting [90, 91].

Concisely, the ownership structure analysis exhibited that as the proportion of FAOWN and FOOWN increased the receipt of modified audit opinions in Jordanian corporates decreased. Consequently, the increase in these types of ownership, thereby, improved quality of financial reporting. Therefore, these findings showing the significant function that ownership of Jordanian corporates plays as CG mechanisms or characteristics.

The audit report lag, LogAuLag, has a positive and insignificant relationship with modified audit opinion at $10 \%$ level, this shows that auditors spend more time and endeavour in their audit work before issuance a qualified opinion. This finding is consistent with Abdoli and Pourkazemi. Absolutely, this finding demonstrates that the long time between the end of the financial year of a firm and the date of the audit report increases the prospect of Jordanian corporates obtaining a modified audit opinion. The result of the regression analysis between firm size (LNASSETS) and modified audit opinion was a positive and insignificant relationship with modified audit opinion at $10 \%$ level. This result suggests that LNASSETS does not impact the modified audit opinion in corporates in Jordan, and this is 
in agreement with Tsipouridou and Spathis who found a significant and positive relationship between LNASSETS and the modified audit report at $\mathrm{p}<0.05$ [102].

A significant and negative relationship was obtained for External Audit Fees (LogEAF) at 5\% level for the association between external audit fees and the modified audit opinion. This result displays that external audit fees have an influence on the issuance of a modified audit opinion for corporates in Jordan. This result indicates that external audit fees enhancement to the supervising processes, increasing the quality of financial statement, and thus, impact the opportunity of corporates in Jordan in obtaining an unmodified audit opinion. This result is not consistence with the past report who did not find any relationship between audit fees and qualified audit opinion [103], whereas Johl, Subramaniam and Zain establish that the audit fees is not correlated with unqualified audit opinion [104].

An insignificant and positive relationship is observed between audit firm size, big4, and the modified audit opinion even at the $10 \%$ level. This result demonstrates that audit firm size (big4) does not enhance the supervising process which directly boosts the quality of financial reporting, thereby impact on the chance of corporates in Jordan to acquire an unmodified audit opinion. The basis for this finding lies in the likelihood that the function of auditors is limited to the limits of mandatory evidence. Mostly, auditors do not need clients to report data in excess of that is demanded by the accounting standards [105, 106, 107]. Similarly, many other studies also reached the same conclusion [Bédard, Coram, Espahbodi \& Mock; Firth, Fung \& Rui; Alsaeed; Arfaoui \& Damak-Ayadi; Pucheta-Martínez \& De Fuentes; Lawrence, Minutti-Meza \& Zhang; Zhang]. Nevertheless, Tsipouridou and Spathis documented a significant and positive relationship with the modified audit report at $\mathrm{p}<0.05$ [102].

Moreover, Leverage (LEV) has a negative relationship with the modified audit opinion at $1 \%$ level. This exhibited that a higher number of leverage adds to a higher acceptance of modified audit report. This result is consistent with Alsaeed who reported that high financial requirement has a negative influence on a firm [109]. LOSS is positively and strongly significant related with the modified audit opinion at $1 \%$ level, which suggests that if a corporate in Jordan experience a loss in a preceding year then the prospect of obtaining a modified audit opinion may likely increase. This result is in concord with that of Firth, Fung and Rui; Arfaoui and Damak-Ayadi; Tsipouridou and Spathis; Abdoli and Pourkazemi; Chen, Peng, Xue, Yang \& Ye; Chen, He, Ma \& Stice and Moalla, who established that companies with accounting losses are more probable to acquire modified audit (unfavourable) opinions. This implies that a modified audit opinion and LOSS have a relatively strong relationship with the supposition that LOSS has a crucial influence on modified audit opinion. Audit effort has a positive and significant association with modified audit opinion at 5\% level, signifying that auditors dedicate some effort in seeking for material misstatements to fulfil their contractual responsibilities. Further, the audit reform has a positive relationship with modified audit opinion at $10 \%$ level, which suggesting that when auditors have a long-term relationship with their users the relationship can lead to a better understanding of the user's financial situation and, so, auditors are more probably to detect financial hitches, and, thus, reduce the prospect of companies in obtaining a modified audit opinion.

\section{Conclusion}

The results showed that both FOOWN and FAOWN are the significant factors reducing modified audit opinions for the Jordanian listed corporates, while the INOWN could impact the issuance of a modified audit report among these corporates. The percentage of FAOWN is higher than both INOWN and FOOWN which indicating that the largest number of corporates have FAOWN. The result of Big4 showed $67 \%$ of corporates audited by Big 4 audit firms. The higher amount of leverage (37.5\%) adds to the higher acceptance of modified audit report. About 34\% of companies reported losses in the previous year, and if a company experiences a loss in the preceding year then resulted in the incidence of a modified audit opinion. Additionally, audit effort has a positive and significant association with modified audit opinion at 5\% level, signifying that auditors dedicate some effort in seeking for material misstatements to fulfil their contractual responsibilities. Further, the audit reform has a positive relationship with modified audit opinion at the $10 \%$ level. Further, the results indicate that the FAOWN had a significant impact on modified audit opinion at $1 \%$ level, however, the direction of impact is negative, which implies that an increase in the percentage of FAOWN in the listed companies increase the quality of financial reporting, in turn, reduce the prospect of the corporates in obtaining a modified audit opinion.

\section{References}

[1] Firth, M., Fung, P. M., \& Rui, O. M. (2007). Ownership, twotier board structure, and the informativeness of earningsEvidence from China. Journal of Accounting and Public Policy, 26 (4), 463-496.

[2] Low, P. Y., \& Majid, A. (2008). CEO dominance, family control and modified audit opinions in Hong Kong. Corporate ownership and Control, 5 (2), 179-186.

[3] Chan, A. L. C., Ding, R., \& Hou, W. (2014). Does mutual fund ownership affect quality of financial reporting for Chinese privately-owned enterprises? International Reopinion of Financial Analysis, 36, 131-140.

[4] Pucheta-Martínez, M. C., \& García-Meca, E. (2014). Institutional investors on boards and audit committees and their effects on quality of financial reporting. Corporate Governance: An International Reopinion, 22 (4), 347-363. 
[5] Alzoubi, E. (2016). Ownership structure and earnings management: Evidence from Jordan. International Journal of Accounting \& Information Management, 24 (2), 135-161.

[6] Yasser, Q. R., Mamun, A. A., \& Hook, M. (2017). The impact of ownership structure on quality of financial reporting in the east. International Journal of Organizational Analysis, 25 (2), 178-197.

[7] Gaio, C., \& Pinto, I. (2018). The role of state ownership on earnings quality: evidence across public and private European firms. Journal of Applied Accounting Research, 19 (2), 312-332.

[8] Tessema, A., Kim, M. S., \& Dandu, J. (2018). The impact of ownership structure on earnings quality: The case of South Korea. International Journal of Disclosure and Governance, 15 (3), 129-141.

[9] Al-Fayoumi, N., Abuzayed, B., \& Alexander, D. (2010). Ownership structure and earnings management in emerging markets: The case of Jordan. International Research Journal of Finance and Economics, 38 (1), 28-47.

[10] Kinney, W. R., \& Martin, R. D. (1994). Does auditing reduce bias in financial reporting? A reopinion of audit-related adjustment studies. Auditing, 13 (1), 149-156.

[11] Francis, J. R., \& Wang, D. (2008). The joint effect of investor protection and Big 4 audits on earnings quality around the world. Contemporary Accounting Research, 25 (1), 157-191.

[12] Moalla, H. (2017). Audit report qualification/modification: Impact of financial variables in Tunisia. Journal of Accounting in Emerging Economies, 7 (4), 468-485

[13] Chen, P. F., He, S., Ma, Z., \& Stice, D. (2016). The information role of audit opinions in debt contracting. Journal of Accounting and Economics, 61 (1), 121-144.

[14] Chen, F., Peng, S., Xue, S., Yang, Z., \& Ye, F. (2016). Do audit clients successfully engage in opinion shopping? Partner-level evidence. Journal of Accounting Research, 54 (1), 79-112.

[15] Boolaky, P. K., \& Quick, R. (2016). Bank directors' perceptions of expanded auditor's reports. International Journal of Auditing, 20 (2), 158-174.

[16] Caramanis, C., \& Lennox, C. (2008). Audit effort and earnings management. Journal of Accounting and Economics, 45 (1), 116-138.

[17] Chen, J., Cumming, D., Hou, W., \& Lee, E. (2013). Executive integrity, audit opinion, and fraud in Chinese listed firms. Emerging Markets Reopinion, 15, 72-91.

[18] Habib, A. (2013). A meta-analysis of the determinants of modified audit opinion decisions. Managerial Auditing Journal, 28 (3), 184-216.

[19] DeAngelo, L. E. (1981). Auditor size and audit quality. Journal of Accounting and Economics, 3 (3), 183-199.

[20] Krishnan, J., Krishnan, J., \& Stephens, R. G. (1996). The simultaneous relation between auditor switching and audit opinion: An empirical analysis. Accounting and Business Research, 26 (3), 224-236.

[21] Miller, D., Le Breton-Miller, I., Minichilli, A., Corbetta, G., \& Pittino, D. (2014). When do Non-Family CEO s Outperform in Family Firms? Agency and Behavioural Agency Perspectives. Journal of Management Studies, 51 (4), 547-572.
[22] Hussainey, K., Tahat, Y., \& Aladwan, M. (2019). The Impact of Corporate Governance on Risk Disclosure: Jordanian Evidence. Academy of Accounting and Financial Studies Journal, 23 (1).

[23] Mitnick, B. M. (2015). Agency theory. Wiley encyclopedia of management, 1-6.

[24] Harindahyani, S., \& Yolino, J. A. (2019). The Role of Firm Ownership Type and Earnings Management on Auditor Choice and Audit Fee of Non-Financial Firms. In Social and Humaniora Research Symposium (SoRes 2018). Atlantis Press.

[25] Jensen, M. C., \& Meckling, W. H. (1976). Theory of the firm: Managerial behavior, agency costs and ownership structure. Journal of Financial Economics, 3 (4), 305-360.

[26] Al-Sa'eed, M. T. A. (2018). The Impact of Ownership Structure and Dividends on Firm's Performance: Evidence from Manufacturing Companies Listed on the Amman Stock Exchange. Australasian Accounting, Business and Finance Journal, 12 (3), 87-106.

[27] Abu Qa'dan, M. B., \& Suwaidan, M. S. (2019). Board composition, ownership structure and corporate social responsibility disclosure: the case of Jordan. Social Responsibility Journal, 15 (1), 28-46.

[28] El-Habashy, H. A. (2019). The Effects of Board and Ownership Structures on the Performance of Publicly Listed Companies in Egypt. Academy of Accounting and Financial Studies Journal, 23 (1).

[29] Bataineh, H., Abuaddous, M., \& Alabood, E. (2018). The Effect of Family Ownership and Board Characteristics on Earnings Management: Evidence from Jordan. Academy of Accounting and Financial Studies Journal.

[30] Saidat, Z., Silva, M., \& Seaman, C. (2019). The relationship between corporate governance and financial performance: Evidence from Jordanian family and nonfamily firms. Journal of Family Business Management, 9 (1), 54-78.

[31] Warrad, L., Abed, S., Khriasat, O., \& Al-Sheikh, I. (2012). The effect of ownership structure on dividend payout policy: Evidence from Jordanian context. International Journal of Economics and Finance, 4 (2), 187-195.

[32] Zeitun, R., \& Gang Tian, G. (2007). Does ownership affect a firm's performance and default risk in Jordan? Corporate Governance: The International Journal of Business in Society, $7(1), 66-82$.

[33] Velury, U., \& Jenkins, D. S. (2006). Institutional ownership and the quality of earnings. Journal of Business Research, 59 (9), 1043-1051.

[34] Almutairi, A. (2013). The impact of institutional ownership and corporate debt on audit quality. Journal of Economic and Administrative Sciences, 29 (2), 134-152.

[35] Lassoued, N., Ben Rejeb Attia, M., \& Sassi, H. (2017). Earnings management and ownership structure in emerging market: Evidence from banking industry. Managerial Finance, 43 (10), 1117-1136.

[36] Velte, P. (2019). What do we know about meta-analyses in accounting, auditing, and corporate governance?. Meditari Accountancy Research, 27 (1), 17-43. 
[37] An, Y. (2015). Does foreign ownership increase quality of financial reporting? Asian Academy of Management Journal, $20(2), 81-101$

[38] Lee, S., Rhee, M., \& Yoon, J. (2018). Foreign monitoring and audit quality: Evidence from Korea. Sustainability, 10 (9), 122. doi: 10.3390/su10093151.

[39] Kim, J. B., Pevzner, M., \& Xin, X. (2019). Foreign institutional ownership and auditor choice: Evidence from worldwide institutional ownership. Journal of International Business Studies, 50 (1), 83-110.

[40] Sachs, J., \& Warner, A. (1995). Economic reform and the process of global integration. Bookings Papers on Economic Activity. Retrieved from https://www.brookings.edu/wpcontent/uploads/1995/01/1995a bpea_sachs_warner_aslund_fischer.pdf

[41] de Albornoz Noguer, B. G., \& Rusanescu, S. (2017). Foreign ownership and quality of financial reporting in private subsidiaries. Working Papers. Serie EC 2017-02. Instituto Valenciano de Investigaciones Económicas, SA (Ivie). Retrieved from https://web2011.ivie.es/downloads/docs/wpasec/wpasec-201702.pdf

[42] Al-Thuneibat, A. A., Khamees, B. A., \& Al-Fayoumi, N. A. (2007). The effect of qualified auditors' opinions on share prices: Evidence from Jordan. Managerial Auditing Journal, 23 (1), 84-101.

[43] Vichitsarawong, T., \& Pornupatham, S. (2015). Do audit opinions reflect earnings persistence? Managerial Auditing Journal, 30 (3), 244-276.

[44] Arfaoui, F., \& Damak-Ayadi, S. (2014). The impact of issuing a qualified audit opinion on auditor switching: an empirical study in the Tunisian context. International Journal of Managerial and Financial Accounting, 6 (3), 189-202.

[45] Farinha, J., \& Viana, L. F. (2009). Board structure and modified audit opinions: evidence from the Portuguese stock exchange. International Journal of Auditing, 13 (3), 237-258.

[46] .Pedro Sánchez Ballesta, J., \& Garcia-Meca, E. (2005). Audit qualifications and corporate governance in Spanish listed firms. Managerial Auditing Journal, 20 (7), 725-738.

[47] Pucheta-Martínez, M. C., Bel-Oms, I., \& Olcina-Sempere, G. (2016). Corporate governance, female directors and quality of financial information. Business Ethics: A European Reopinion, 25 (4), 363-385.

[48] Shbeilat, M. K. (2019). International Standard on Auditing No. 260 and Audit Quality: Evidence from Jordan. International Business Research, 12 (4).

[49] Jordanian Companies Law 22. (2017). Available from https://www.sdc.com.jo/english/index.php?option=com content\&task $=$ opinion\&id $=254$

[50] Alkhatib, K., \& Marji, Q. (2012). Audit reports timeliness: Empirical evidence from Jordan. Procedia-Social and Behavioral Sciences, 62, 1342-1349.

[51] Cha, M., Hwang, K., \& Yeo, Y. (2016). Relationship between audit opinion and credit rating: Evidence from Korea. Journal of Applied Business Research, 32 (2), 621-634.

[52] Sirois, L. P., Bédard, J., \& Bera, P. (2018). The informational value of key audit matters in the auditor's report: Evidence from an eye-tracking study. Accounting Horizons, 32 (2), 141-162.

[53] Fakhfakh, H., \& Fakhfakh, M. (2010). The impact of Revised ISA 700: an international empirical comparison. International Journal of Accounting, Auditing and Performance Evaluation, $6(2-3), 274-326$.

[54] Gold, A., Gronewold, U., \& Pott, C. (2012). The ISA 700 auditor's report and the audit expectation gap-do explanations matter?. International Journal of Auditing, 16 (3), 286-307.

[55] Downey, D. H., \& Bedard, J. C. (2018). Coordination and communication challenges in global group audits. Auditing: $A$ Journal of Practice and Theory, 1-43.

[56] International Auditing and Assurance Standard Board (IAASB). (2009). Audit considerations in respect of going concern in the current economic environment. Available from https://www.ifac.org/publications-resources/staff-auditpractice-alert-audit-considerations-respect-going-concerncurrent

[57] Fakhfakh, M. (2015). The readability of international illustration of auditor's report: An advanced reflection on the compromise between normative principles and linguistic requirements. Journal of Economics, Finance and Administrative Science, 20 (38), 21-29.

[58] Jordanian Companies Law 22. (1997). Retrieved from http://hammourilaw.com/Hammouri_Resorces/Articals/ Definitions\%20and\%20General\%20Provisions.pdf

[59] Ramalho, J. J. S., Rita, R. M. S. \& da Silva, J. V. (2018). The impact of family ownership on capital structure of firms: exploring the role of zero-leverage, size, location and the global financial crisis. International Small Business Journal, $36(5), 574-604$.

[60] Basco, R. (2015). Family business and regional development-A theoretical model of regional familiness. Journal of Family Business Strategy, 6 (4), 259-271.

[61] Al-matarneh, G. F. (2012). The extent of adherence of Jordanian auditors in implementing the international standard on auditing ISA 700. International Management Reopinion, 7 (1), 22-29.

[62] Miller, D., Le Breton-Miller, I., \& Scholnick, B. (2008). Stewardship vs. stagnation: An empirical comparison of small family and non-family businesses. Journal of Management Studies, 45 (1), 51-78.

[63] Revilla, A. J., Pérez-Luño, A., \& Nieto, M. J. (2016). Does family involvement in management reduce the risk of business failure? The moderating role of entrepreneurial orientation. Family Business Reopinion, 29 (4), 365-379.

[64] Shyu, J. (2011). Family ownership and firm performance: Evidence from Taiwanese firms. International Journal of Managerial Finance, 7 (4), 397-411.

[65] Fama, E. F., \& Jensen, M. C. (1983). Separation of ownership and control. The Journal of Law and Economics, 26 (2), 301-325.

[66] Wang, J., \& Song, L. (2006). Timeliness of annual reports of Chinese listed companies. Journal of Chinese Economic and Business Studies, 4 (3), 241-257.

[67] Tong, Y. H. (2007). Financial reporting practices of family firms. Advances in Accounting, 23, 231-261. 
[68] Ali, A., Chen, T. Y., \& Radhakrishnan, S. (2007). Corporate disclosures by family firms. Journal of Accounting and Economics, 44 (1-2), 238-286.

[69] Cascino, S., Pugliese, A., Mussolino, D., \& Sansone, C. (2010). The influence of family ownership on the quality of accounting information. Family Business Reopinion, 23 (3), 246-265.

[70] Lourenço, I., Branco, M., \& Dias Curto, J. (2018). Timely reporting and family ownership: The Portuguese case. Retrieved from http://www.centrobaffi.unibocconi.it/wps/allegatiCTP/Timely $\% 20$ reporting\%20 and $\% 20$ family\%20ownership_1.pdf

[71] Ho, J. L., \& Kang, F. (2013). Auditor choice and audit fees in family firms: Evidence from the S\&P 1500. Auditing: $A$ Journal of Practice \& Theory, 32 (4), 71-93.

[72] Martínez, J. I., Stöhr, B. S., \& Quiroga, B. F. (2007). Family ownership and firm performance: Evidence from public companies in Chile. Family Business Reopinion, 20 (2), 83-94.

[73] Al-Dubai, S., Ismail, K., Izah, K. N., \& Amran, N. A. (2014). Family involvement in ownership, management, and firm performance: Moderating and direct-effect models. Asian Social Science, 10 (14), 193-205.

[74] Hiebl, M. R. (2012). Peculiarities of financial management in family firms. The International Business \& Economics Research Journal (Online), 11 (3), 315-322.

[75] Lago-Peñas, S., Álvarez-Santullano, M. M., Rivo-López, E., \& Villanueva-Villar, M. (2017). Determining factors for audit opinion in private family and non-family firms. Evidence from Spain (No. 1701). Universidade de Vigo, GEN-Governance and Economics research Network. Retrieved from http://infogen.webs.uvigo.es/WPC/WP1701.pdf

[76] Jiraporn, P., \& DaDalt, P. J. (2009). Does founding family control affect earnings management? Applied Economics Letters, 16 (2), 113-119.

[77] Hashmi, M. A., Brahmana, R. K., \& Lau, E. (2018). Political connections, family firms and earnings quality. Management Research Reopinion, 41 (4), 414-432.

[78] Kazemian, S., \& Sanusi, Z. M. (2015). Earnings management and ownership Structure. Procedia Economics and Finance, $31,618-624$.

[79] Alves, S. (2012). Ownership structure and earnings management: Evidence from Portugal. Australasian Accounting. Business and Finance Journal, 6 (1), 57-74.

[80] Kouaib, A., \& Jarboui, A. (2014). External audit quality and ownership structure: interaction and impact on earnings management of industrial and commercial Tunisian sectors. Journal of Economics Finance and Administrative Science, 19 (37), 78-89.

[81] Chan, K. H., Lin, K. Z., \& Zhang, F. (2007). On the association between changes in corporate ownership and changes in auditor quality in a transitional economy. Journal of International Accounting Research, 6 (1), 19-36.

[82] Mitra, S., Hossain, M., \& Deis, D. R. (2007). The empirical relationship between ownership characteristics and audit fees. Reopinion of Quantitative Finance and Accounting, 28 (3), 257-285.
[83] Soliman, M., \& Elsalam, M. (2013). Corporate governance practices and audit quality: An empirical study of the listed companies in Egypt. World Academy of Science, Engineering, and Technology, 71, 1292-1297. Available from https://papers.ssrn.com/sol3/papers.cfm?abstract_id=2257815

[84] Ajay, R., \& Madhumathi, R. (2015). Institutional ownership and earnings management in India. Indian Journal of Corporate Governance, 8 (2), 119-136.

[85] Klapper, L. F., Laeven, L., \& Love, I. (2006). What drives corporate governance? Firm - level evidence from Eastern Europe. World Bank Policy Research Working Paper Series No. $3600 . \quad$ Retrieved from http://documents.worldbank.org/curated/en/813551468299116 185/pdf/wps3600.pdf

[86] Waweru, N. (2014). Determinants of quality corporate governance in Sub-Saharan Africa: Evidence from Kenya and South Africa. Managerial Auditing Journal, 29 (5), 455-485.

[87] Aggarwal, R., Erel, I., Ferreira, M., \& Matos, P. (2011). Does governance travel around the world? Evidence from institutional investors. Journal of Financial Economics, 100 (1), 154-181.

[88] Ferreira, M. A., \& Matos, P. (2008). The colors of investors' money: The role of institutional investors around the world. Journal of Financial Economics, 88 (3), 499-533.

[89] Beuselinck, C., Blanco, B., \& García Lara, J. M. (2017). The role of foreign shareholders in disciplining financial reporting. Journal of Business Finance \& Accounting, 44 (5-6), 558-592.

[90] Beuselinck, C., Blanco, B., \& Garcia Lara, J. M. (2013). The role of foreign shareholders in disciplining financial reporting. IESEG School of Management. Lille Catholic University 3, Lille, France. Paper retrieved from http://www. ieseg. fr/w p-content/uploads/2013-MAN-07_Beuselinck. pdf.

[91] Nelson, S. P., \& Mohamed-Rusdi, N. F. (2015). Ownership structures influence on audit fee. Journal of Accounting in Emerging Economies, 5 (4), 457-478.

[92] Alzeaideen, K. A., \& Al-Rawash S. Z. (2018). The effect of ownership structure and corporate debt on audit quality: Evidence from Jordan. International Journal of Economics and Financial Issues, 8 (3), 51-58.

[93] Guo, J., Huang, P., Zhang, Y., \& Zhou, N. (2015). Foreign ownership and real earnings management: Evidence from Japan. Journal of International Accounting Research, 14 (2), 185-213.

[94] Hashim, J. B. (2017). Does ownership characteristics have any impact on audit report lag? Evidence of Malaysian listed companies. World Applied Sciences Journal, 35 (9).

[95] Alzoubi, E. S. S. (2018). Audit quality, debt financing, and earnings management: Evidence from Jordan. Journal of International Accounting, Auditing and Taxation, 30 (C), 6984.

[96] Alzoubi, E. S. S. (2019). Audit committee, internal audit function and earnings management: evidence from Jordan. Meditari Accountancy Research, 27 (1), 72-90.

[97] Alabdullah, T. T. Y., Yahya, S., \& Ramayah, T. (2014). Corporate governance mechanisms and Jordanian companies' financial performance. Asian Social Science, 10 (22), 247-262. 
[98] Idris, M., Siam, Y. A., \& Nassar, M. (2018). Board independence, earnings management and the moderating effect of family ownership in Jordan. Management \& Marketing, 13 (2), 985-994.

[99] Midi, H., Sarkar, S. K., \& Rana, S. (2010). Collinearity diagnostics of binary logistic regression model. Journal of Interdisciplinary Mathematics, 13 (3), 253-267.

[100] Makhlouf, M. H., Ali, N. H. L. M. Y., \& Ramli, B. N. A. (2017). Board of directors' effectiveness and firm performance: Evidence from Jordan. Research Journal of Finance and Accounting, 8 (18), 23-34.

[101] Abdoli, M., \& Pourkazemi, A. (2014). Effect of executive board and family control on audit opinion. African Journal of Business Management, 8 (18), 810-815.

[102] Tsipouridou, M., \& Spathis, C. (2014). Audit opinion and earnings management: Evidence from Greece. Accounting Forum, 38 (1), 38-54.

[103] Ishak, S., Yusof, M., \& Atef, M. (2013). The formation of separate risk management committee and the effect on modified audit report. Malaysian Management Journal (MMJ), 17, 43-58.

[104] Johl, S., Subramaniam, N., \& Zain, M. M. (2012). Audit committee and CEO ethnicity and audit fees: some Malaysian evidence. The International Journal of Accounting, 47 (3), 302-332.

[105] Malek, M., Ahmad, A. C., \& Malek, S. (2012). The effect of director-auditor link on non-audit services fee. In Corporate Governance Practices in Malaysia (pp. 158-176). Selangor, Malaysia: Universiti Malaysia Press.

[106] Obaidat, A. N. (2007). Auditors compliance with international standards on auditing (ISAs): Evidence form Jordan. Journal of Social Sciences, 3 (4), 185-189.

[107] Hodgdon, C., Tondkar, R. H., Adhikari, A., \& Harless, D. W.
(2009). Compliance with International Financial Reporting Standards and auditor choice: New evidence on the importance of the statutory audit. The International Journal of Accounting, 44 (1), 33-55.

[108] Bédard, J., Coram, P., Espahbodi, R., \& Mock, T. J. (2016). Does recent academic research support changes to audit reporting standards?. Accounting Horizons, 30 (2), 255-275.

[109] Alsaeed, K. (2006). The association between firm-specific characteristics and disclosure: The case of Saudi Arabia. Managerial Auditing Journal, 21 (5), 476-496.

[110] Pucheta-Martínez, M. C., \& De Fuentes, C. (2007). The impact of audit committee characteristics on the enhancement of the quality of financial reporting: An empirical study in the Spanish context. Corporate Governance: An International Reopinion, 15 (6), 1394-1412.

[111] Lawrence, A., Minutti-Meza, M., \& Zhang, P. (2011). Can Big 4 versus non-Big 4 differences in audit-quality proxies be attributed to client characteristics? The Accounting Reopinion, 86 (1), 259-286.

[112] Zhang, J. H. (2012). Accounting comparability, audit effort and audit outcomes. Contemporary Accounting Research, 35 (1), 245-276.

[113] Wu, C. Y. H., Hsu, H. H., \& Haslam, J. (2016). Audit committees, non-audit services, and auditor reporting decisions prior to failure. The British Accounting Reopinion, 48 (2), 240-256.

[114]Fang, J., Haw, I.-M., Yu, V., \& Zhang, X. (2014). Positive externality of analyst coverage upon audit services: Evidence from China. Asia Pacific Journal of Accounting \& Economics, 21(2), 186-206.

[115] Rodgers, W., Guiral, A., \& Gonzalo, J. A. (2019). Trusting/Distrusting Auditors' Opinions. Sustainability, 11(6), 1666. 